\title{
ПСИХОЛОГІЧНІ ПЕРЕДУМОВИ ФОРМУВАННЯ МОВНОЇ ОСОБИСТОСТІ УЧНІВ ОСНОВНОї ШКОЛИ
}

Цоуфал Л. С. Психологічні передумови формування мовної особистості учнів основної школи.

У статті розкрито сутність поняття «мовна особистість», охарактеризовано структуру мовної особистості, з'ясовано психологічні передумови навчання мови. здібності.

Ключові слова: мовна особистість, структура мовної особистості, мотиви, мовні

Цоуфал Л. С. Психологические предпосылки формирования языковой личности учащихся основной школы.

В статье раскрывается смысл понятия «языковая личность», характеризуется структура языковой личности, объясняются психологические предпосылки в обучении языка.

Ключевые слова: языковая личность, структура языковой личности, мотивы, языковые способности.

Tsoufal L. S. The psychological reasons of the linguistic personality of the basic school.

The article reveals the nature of the concept «the linguistic personality, the structure of the linguistic personality» is characterized, the psychological reasons of language teaching are also revealed here.

Key words: linguistic personality, structure of the linguistic personality, motives, linguistic skills. 
Одним із стратегічних завдань реформування змісту мовної освіти $\epsilon$ створення системи та визначення обсягу знань про мову і мовлення, мовних і мовленнєвих умінь та навичок, досвіду творчої діяльності та емоційно-ціннісного ставлення до світу. У сучасних умовах базової школи домінантною стає особистісна орієнтація навчання, яка передбачає забезпечення оптимальних умов для різнобічного мовленнєвого розвитку кожного учня, урахування його індивідуальних особливостей, пізнавальних потреб, інтересів, прагнень, заохочення до самопізнання i саморозвитку.

Володіння рідною мовою, уміння спілкуватися, досягати успіху в процесі комунікації є тими характеристиками особистості, які визначають досягнення людини в багатьох галузях життя, сприяють іiі соціальній адаптації до умов сучасного світу.

Рідна мова - основа становлення пізнавальної сфери особистості, оскільки забезпечує розвиток іiі інтелекту, сприяє подальшому вдосконаленню понятійного апарату. У зв'язку 3 цим особливої актуальності набуває проблема формування мовної особистості, яка володіє вміннями й навичками комунікативно доцільно користуватися мовними засобами в усіх видах мовленнєвої діяльності.

Мовна особистість як лінгвістична і лінгводидактична категорія перебуває в полі зору багатьох дослідників (3. Бакум, М. Вашуленко, О. Горошкіна, В. Дороз, С. Срмоленко, С. Караман, Л. Мацько, Л. Паламар, М. Пентилюк, Т. Симоненко, Н. Шумарова). Особистісний аспект вивчення мови знайшов відображення в працях психологів i психолінгвістів (Л. Виготський, М. Жинкін, І. Зимня, Г. Костюк, О. Леонтьєв, А. Маркова, С. Рубінштейн, Б. Теплов).

Пошук шляхів формування мовної особистості пов'язаний із дослідженням комплексу питань, одним із яких $\epsilon$ з'ясування психологічних умов мовленнєвого розвитку учнів.

Термін «мовна особистість» уперше вжив Ю. Караулов. Російський учений розкриває зміст цього поняття, розробив структуру й визначив рівні мовної особистості - вербально-семантичний, тезаурусний, прагматичний (мотиваційний). Науковець зазначає, що мовною особистістю $\epsilon$ «сукупність здібностей i характеристик людини, що зумовлюють створення і сприйняття нею мовленнєвих творів (текстів), які різняться а) ступенем структурно-мовної складності, б) глибиною і точністю відображення дійсності, в) певною цільовою спрямованістю» [4].

Ю. Караулов висловлює думку про те, що структура мовної особистості на кожному рівні складається зі специфічних типів елементів: одиниць відповідного рівня, відношень між ними і стереотипних їх об'єднань, особливих, притаманних кожному рівню утворень. Дослідник вважає, що на нульовому (вербально-семантичному) рівні структура мовної особистості складається 3 окремих слів як одиниць вербально- 
асоціальної мережі, причому відношення між ними охоплює всю різноманітність їх парадигматичних, синтагматичних, дериваційних та інших зв'язків у їх сукупності.

На лінгвокогнітивному (тезаурусному) рівні одиницями є узагальнені поняття, великі концепти, ідеї, що в кожної мовної індивідуальності складаються в упорядковану, більше або менше систематизовану «картину світу», що відображає ієрархію цінностей. Когнітивний рівень передбачає розширення значення i перехід до знань, а значить, охоплює інтелектуальну сферу особистості, що дає досліднику вихід через мову, через процеси говоріння і розуміння - до знань, свідомості, процесів пізнання людини. Третій рівень передбачає мету, мотиви, інтереси, установки, інтенціональність, забезпечує в аналізі мовної особистості закономірний і зумовлений перехід від оцінок ії мовленнєвої діяльності до осмислення реальної діяльності в світі.

Українські лінгводидакти (3. Бакум, Т. Донченко, С. Єрмоленко, С. Караман, Л. Мацько, В. Мельничайко, М. Пентилюк, Л. Скуратівський), визначаючи сучасні підходи до реалізації мети мовної освіти, акцентують, що саме на шкільному етапі оволодіння українською мовою як рідною i державною закладаються основи й розгортається процес формування мовної особистості - людини, яка виявляє високий рівень мовної i мовленнєвої компетенції, представляє себе в суспільстві засобами мови.

На думку М. Пентилюк, «мовна особистість - це людина, яка не тільки знає українську мову, а й постійно використовує її в повсякденному спілкуванні, а головне - любить, шанує і дбає про ії̈ збагачення й розвиток, людина, для якої стає престижним користуватися мовою, що має давню історію й належить до найрозвиненіших мов світу» [5, с.2]. Складовою розвитку мовлення особистості $є$ ïi духовне становлення, виховання любові й поваги до рідного слова, народу, усвідомлення необхідності та внутрішньої потреби в спілкуванні й пізнанні світу засобами рідної мови.

Особистістю людина стає не відразу, вона виховується поступово, і в iii формуванні бере участь багато зовнішніх чинників. Серед них одне 3 чільних місць належить мові. Потреба у спілкуванні, мовленні поряд із потребою в діяльності, праці є визначальною в становленні особистості. Мова найглибше пронизує свідомість і підсвідомість людини й доносить до них величезну частку інформації про зовнішній світ, закономірності його функціонування.

За визначенням I. Ющука, мова є продуктом підсвідомої аналітичної діяльності сотень поколінь і мільйонів особистостей. У iї структурі, в моделях побудови словосполучень і речень акумульовано те, що люди мільйони разів засвоювали інтуїтивно й потім стільки ж разів перевіряли на практиці, тобто мова вже своїм ладом, своєю структурою несе певні відомості про навколишнє середовище, про його структуру, про орієнтацію в ньому. Учений зауважує, що дитина в дво-трирічному віці оволодіває 
граматикою рідної мови, тому що, сприймаючи мовлення інших людей, iї підсвідомість у поєднанні слів, у побудові речень виділяє закодовані об'єктивні закономірності, досвід багатьох поколінь. Разом із засвоєнням мови в підсвідомості людини закладається внутрішній план можливих дій, створюються моделі вчинків, які реалізуються у відповідній ситуації $[8$, с. 43$]$.

У процесі навчання мови необхідно дбати не стільки про засвоєння граматичних правил, скільки про те, щоб учні правильно, не перекручено відчували й сприймали їі внутрішні закони. Для цього потрібно розглядати мовний матеріал систематично, у логічній послідовності i внутрішньопредметних зв'язках.

Мовленнєва поведінка особистості знаходиться під впливом чинників соціального і особистісного плану, що перебувають у взаємозв'язку. Їхнє значення різне, однак урахування кожного з них необхідне для створення цілісної картини вербальної поведінки мовної особистості. Ученими доведено: у результаті входження людини в соціальні відносини відбувається становлення мовної особистості, мовленнєво-мисленнєва діяльність якої формується за нормами й еталонами певної етномовної культури.

Показником мовного розвитку особистості є комунікативність, тобто здатність спілкуватися, що зумовлює використання засобів мови, уміння сприймати та відтворювати зміст чужого висловлювання і продукувати власне. Передумови формування мовленнєвої здатності як однієї з вищих функцій людини забезпечуються діяльністю, якою вона оволодіває у процесі своєї соціалізації. Роль діяльності є визначальною, оскільки лише в iii структурі розгортається мовленнєве спілкування, виникає потреба в різних поняттях, узагальненнях, судженнях.

Аналіз психологічних досліджень Л. Виготського, І. Зимньої, О. Леонтьєва, С. Рубінштейна дозволяє говорити про те, що успішність формування мовної особистості учня залежить від рівня комунікативного розвитку дитини в рідній мові.

Поняття «комунікативний розвиток у рідній мові», за визначенням I. Зимньої, слід розглядати як складне багатоаспектне явище, що передбачає: обсяг словника дитини; рівень засвоєння мовних правил; рівень володіння усними формами спілкування, показниками якого слугують уміння дитини свідомо будувати зв'язне висловлювання, адекватно реагувати на репліки співрозмовника, висловлювати своє ставлення до почутого; рівень володіння технікою читання, показником чого $є$ темп читання; рівень сформованості навичок письма; рівень розвитку психічних функцій дитини: сталості уваги, сприйняття, запам'ятовування, чутливості фонематичного та інтонаційного слуху, обсяг слухової короткочасної і довготривалої пам'яті, функціонування механізмів мислення, у тому числі й рефлексії (здатності до міркувань, 
аналізу власних думок, почуттів); рівень сформованості пізнавальних інтересів, загальний кругозір учнів [3, с. 126-127].

Комунікативний розвиток у рідній мові правомірно розглядати в загальному контексті соціалізації кожної дитини, тобто 3 погляду сформованості вмінь спілкування 3 ровесниками, дорослими, а також 3 позиції загальної ситуації розвитку учня.

Успішність оволодіння мовою зумовлена мотиваційним чинником $\mathrm{i}$ рівнем сформованості загальнонавчальних умінь учня. Згідно з концепцією Д. Ельконіна, у процесі розвитку дитини спочатку має відбутися засвоєння мотиваційного аспекту діяльності, а потім операційно-технічного. Учені визначають такі мотиви: суспільно-політичні (державність української мови, обов'язок учитися в школі); професійно-ціннісні (професійне навчання здійснюється державною мовою); соціального престижу, громадського обов'язку; комунікативні мотиви (потреба спілкуватися українською мовою); мотиви, пов’язані 3 потребою самовиховання, прагнення до самовдосконалення; утилітарні (потреба в знаннях мови як засобу досягнення певних життєвих вигод); мотиви тривожності (не підвести клас, не одержати низький бал); мотив поваги до вчителя української мови і літератури.

Значення для дитини тих чи тих мотивів залежить від віку, рівня іiі вихованості, розумових здібностей та інтелектуального розвитку, суспільних і соціальних умов, у яких проходить навчання тощо.

Формування позитивної мотивації навчальної діяльності - одне 3 важливих завдань індивідуалізації, диференціації та інтенсифікації навчання української мови в основній школі.

3-поміж психологічних передумов, які впливають на рівень формування мовної особистості, особливе значення мають мовні здібності. Психологами (Б. Теплов, С. Рубінштейн, О. Леонтьєв) теоретично обгрунтовано поняття здібностей та виокремлено три базових ознаки:

- здібності - індивідуально-психологічні особливості, за якими люди відрізняються один від одного, а не властивості, за якими всі рівні;

- здібності - це лише ті індивідуальні особливості, які зумовлюють успішність діяльності; не окремі здібності, а своєрідне поєднання цих здібностей може забезпечити успішність виконання діяльності;

- поняття здібностей не зводиться до знань, умінь і навичок, які вже сформовані в людини, але обумовлюють швидкість, легкість та успішність формування цих знань, умінь і навичок.

Б. Теплов заперечував природженість здібностей. Учений зауважував, що природженими можуть бути лише анатомо-фізіологічні особливості, тобто задатки, покладені в основі розвитку здібностей. С. Рубінштейн відзначав складну синтетичність здібностей як особливостей особистості, яка загалом визначає здатність особистості до історично сформованої діяльності. 
У психологічній літературі розрізняють загальні та спеціальні здібності. До загальних здібностей віднесять інтелект, креативність i научуваність. Спеціальні здібності розмежовують за видами психічних функціональних систем (сенсомоторні, перцептивні, мнемічні, імажитивні, мислиннєві, комунікативні), властивостями яких вони $є$, та зумовлюють успішність окремих видів діяльності. За видами діяльності дослідники виділяють такі спеціальні здібності, як математичні, літературні, педагогічні, художні, психолінгвістичні здібності - у діяльності опанування мови тощо.

Здібності людини визначаються діапазоном тих можливостей до засвоєння нових знань, їх застосуванням до творчого розвитку, які відкривають засвоєння цих знань.

Відправним пунктом розвитку здібностей людини $є$ функціональна специфіка різноманітних модальностей чуттєвості. Так, на основі загальної слухової чуттєвості в процесі спілкування, що здійснюється засобами мови, у людини формується мовленнєвий, фонетичний слух, детермінований фонетичною будовою рідної мови.

Суттєвим «механізмом» формування фонетичного чуття $\epsilon$ генералізована система певних фонетичних відношень. Важливу роль у формуванні здібностей до засвоєння мови відіграє не тільки генералізація фонетичних відношень, але й тих, що покладені в основу словотворення $\mathrm{i}$ словозміни. Здібним до засвоєння мови вважається той, у кого легко i швидко, 3 найменшої кількості спроб, здійснюється генералізація відношень, зосереджених на словотворенні і словозміні, і в результаті перенесення цих відношень на інші випадки.

Як зазначає С. Рубінштейн, здібність як властивість особистості повинна виражатися в діях, що уможливлюють перенесення з одних умов на інші, з одного матеріалу на інший. Тому в основі здібностей має міститися узагальнення. Узагальнення відношень $є$ необхідним компонентом усіх здібностей, мовних зокрема, але в кожній здібності відбувається узагальнення інших відношень, іншого матеріалу [7, с. 547].

Оскільки успішність навчальної роботи учня залежить певною мірою від його здібностей, а розвиток, формування здібностей залежить від того, як дитина засвоює знання, перед учителем стоїть завдання: ураховуючи здібності учнів в усій різноманітності й індивідуальних особливостях, водночас і формувати їх у певному напрямку. Якими б не були здібності людини, вони тісно пов'язані з ії інтелектом, волею, темпераментом, характером - усім психічним складом особистості в цілому. Між усебічним розвитком здібностей та інтересів наявний тісний взаємозв'язок: розвиток здібностей здійснюється в діяльності, що стимулюється інтересами, а інтерес до діяльності утримується іiі успішністю, яка у свою чергу зумовлена відповідними здібностями. Очевидно, здібності, справжній талант визначають покликання людини, що виявляється у 
спрямованості інтересів. Розвиток мовних здібностей учнів має перебувати в колі постійної уваги учителя-словесника, стимулювання інтересу до мовленнєвої діяльності сприятиме вихованню гармонійної особистості.

Мовна особистість виявляє себе в актах мовленнєвої діяльності, що формується під впливом психологічних процесів. Як зазначає Р. Дружененко, національний компонент мовної особистості дозволяє розглядати мовленнєву діяльність під кутом національно-культурної специфіки i враховувати етнопсихологічні чинники: вроджені мовні здібності, чуття мови, національний спосіб мислення, національна свідомість і самосвідомість, національно-мовна свідомість, національний характер, менталітет, національно-культурна мотивація [1, с. 7].

У зв'язку із завданнями сучасної мовної освіти Л.Мацько визначає найважливіші складники мовної особистості:

- мовнокомунікативні суспільні запити, мотиваційні потреби i досконалі компетенції;

- грунтовні мовні знання і мобільність їх використання;

- мовна свідомість і усвідомлення себе мовними українськими особистостями; мова $є$ для кожної особистості справою національнокультурного самовизначення;

- національна культуровідповідність мовної особистості; знання концептів і мовних знаків національної культури;

- мовна здатність і мовна здібність; мовне чуття, мовний смак;

- усвідомлена естетична мовна поведінка; мовна стійкість.

Поділяємо думку С. Срмоленко, Л. Мацько, які підкреслюють, що мовна особистість - це узагальнений образ носія мовної свідомості, національної мовної картини світу, мовних знань, умінь і навичок, мовних здатностей і здібностей, мовної культури і смаку, мовних традицій і мовної моди [2, с. 120].

Формування мовної особистості не обмежується термінами шкільної освіти, а триває все свідоме життя людини. Визначаючи структуру поняття «мовна особистість», М. Пентилюк, Л. Скуратівський, Г. Шелехова називають такі складові: мовна компетенція; мовленнєва компетенція; предметна компетенція; прагматична компетенція;, комунікативна компетенція; постійний інтелектуальний розвиток - розвиток психічних процесів (пам'яті - зорової та слухової, мислення - абстрактного й образного, спостереження, уяви - репродуктивної й творчої); духовне багатство особистості - постійний духовний розвиток, дотримання моральних, етичних норм, насамперед етики спілкування; акумулювання мовних традицій [6, с. 192-193]. Представлена модель засвідчує увагу методистів до психологічних чинників формування мовної особистості, підкреслює необхідність вироблення в кожного учня прагнення до самовдосконалення, саморозвитку.

Отже, процес навчання рідної мови необхідно спрямувати на виховання інтелектуально розвинених, мислячих, національно свідомих особистостей, якими повинні стати випускники сучасної школи. 


\section{Література}

1. Дружененко Р. С. Етнопедагогічні засади формування мовленнєвих умінь i навичок учнів основної школи: автореф. дис. ... канд. пед. наук: 13.00.02 / Р. С. Дружененко. - Херсон, 2005. - 18 с.

2. Єрмоленко С. Формування української мовної особистості / Світлана Єрмоленко // Українознавство. - 2010. - №1. - С. 120-123.

3. Зимняя И. Я. Психология обучения иностранным языкам в школе / И. Я. Зимняя. - М.: Просвещение, 1991. - 222 с.

4. Караулов Ю. Н. Русская языковая личность и задачи ее изучения / Язык и личность. - М.: Наука, 1989. - 216с. [Електронний ресурс]. - Режим доступу: destructioen.narod.ru/karaulov_jasikovaja_lichnost.htm

5. Пентилюк М. Компетентнісний підхід до формування мовної особистості в євроінтеграційному контексті / Марія Пентилюк // Українська мова i література в школі. - 2010. - №2. - С. 2-5.

6. Практикум з методики навчання української мови / [М. І. Пентилюк, С. О. Караман, О. В. Караман та ін.]; за ред. М. І. Пентилюк. - К.: Ленвіт, 2003. - 302 с.

7. Рубинштейн С. Л. Основы общей психологии / С. Л. Рубинштейн. - СПб: Питер, 2009. - 713 с. (Серия «мастера психологии»).

8. Ющук І. Психологічний аспект у методиці викладання рідної мови / Iван Ющук // Дивослово. - 1999. - №8. - С. 42-44.

Стаття надійшла до редакиіï 26.10.2010 p. 